\title{
Study of teenage students' musculoskeletal health, teenage students training program: the application of intervention mapping approach
}

Nazila NeJhaddadgar

Ardebil University of Medical Sciences

Sedigheh Sadat Tavafian

Tarbiat Modares University Faculty of Medical Sciences

arash ziapour ( $\sim$ arashziapoor@gmail.com )

Kermanshah University of Medical Sciences https://orcid.org/0000-0001-8687-7484

Jaffar Abbas

Shanghai Jiao Tong University

Research

Keywords: Health education, adolescent, Musculoskeletal health

Posted Date: June 25th, 2021

DOI: https://doi.org/10.21203/rs.3.rs-180537/v2

License: (a) (i) This work is licensed under a Creative Commons Attribution 4.0 International License.

Read Full License 


\section{Abstract}

Background: According to the studies conducted, adolescence and its related health issues are of the most significant issues. The purpose of the study was to develop a Musculoskeletal Health interventiontraining program using intervention mapping approach (IMA).

Methods: The present study was a study protocol where IMA was used as a planning framework for developing musculoskeletal Health intervention-training program. Six intervention mapping steps were completed in the study. As the first step, needs assessment was performed by reviewing the studies, qualitative evaluation and interviews. In the second step, matrix of change objectives was designed. Later on, after designing the program and planning the program implementation, the program evaluation plan was developed.

Results: IMA guided us in designing and implementing a control-oriented training program with the participation of the participants along with the definition of outcomes, performance goals and determinants, theoretical methods and practical applications, intervention program, implementation and step by step assessment.

Conclusion: Intervention mapping is a participation-based approach to design and implement promotion programs.

\section{Background}

According to the statute of the World Health Organization (WHO), health is considered as one of the most obvious human rights and needs [1]. Adolescence is one of the most significant periods in every person's life [2]. According to a report by WHO, one out of every five people is adolescent [3]. Today, the backpack is one of the most popular kinds of bags among teenage students which has been noticed by many researchers from different aspects since backpack is one of the most important factors which creates musculoskeletal injuries in Teenage students [4, 5]. A heavy backpack makes a person arche his/her back more than usual or bend his/her head and pull forward his body to tolerate the weight of the backpack. And the pressure on the muscles of the neck and back can cause fatigue, injury, and finally anomalies of the spine [6]. American Academy of Orthopedic Surgeons stated that the properties of a good backpack are having two shoulder straps, back pads, waistband, low weight, and wheels [7]. In different ages, the effect of cargo transportation varies. During 12-14 years old, the spine is growing rapidly and any kind of stress on the spine manifests itself as pain and discomfort [8]. These studies showed that when the weight of backpacks is more than the specified standard it leads to pain in the back and the upper parts of the body. Also, carrying these bags, in the long run, leads to drooping shoulders and kyphosis [9].

In recent years, carrying and using tools and backpacks has been considered as risk factors for musculoskeletal disorders [10-13]. The findings of some studies show that between 40 and 88 percent of students complain about the pain on their shoulders, neck, and back when they carry their backpacks. 
Moreover, between 30 to 80 percent of them believe that their musculoskeletal problems are related to carrying backpacks [10].

Training is a process that bridges the gap between health information and behavior, and given the relationship between knowledge, attitude and performance improvement in an intervention-training process, the significance of proper information provision and the provision of learning opportunities for Teenage students become evident [11]. Designing a targeted intervention program needs using an evidence-based planning framework, the theory and curriculum for adolescent special education programs. Different models have been developed for designing, implementing, and evaluation of training programs by experts, one of which is IMA[9]. This approach is a planning approach based on the significance of developing evidence-based programs that assess and intervene in health-related issues [10].

IMA has a problem solving-based approach and enables the implementation of the program through six steps: need assessment, objectives matrix design, selection of theory and practical application-based intervention methods, production of components and materials of the intervention program, adoption planning, implementation and sustainability and evaluation [11]. This approach focuses on behavioral change and the individuals who are influential on the behavior of those at risk known as environmental agents and individuals' health issues at different ecological levels to make changes [12]. The aim of the current study is to prepare an intervention plan to reduce musculoskeletal damage due to the use of a backpack.

\section{Results}

The present study is the description of a study conducted to develop a training-intervention program using IMA. Intervention mapping has six steps and some tasks at each step, where the basic processes are used in completing each step to benefit from theories and models.

\section{Step 1: needs assessment}

As the first part of intervention mapping, needs assessment is defined as a systematic study to identify the difference between what the status is and what should be in a given group and the intended state [13, 14]. In the current study, the planning group was established to identify the health issue, and examine the life quality of teenage students with the presence of stakeholders in health education, Orthopedic specialist, school principals, health educators, parents, and student, was examined using health needs assessment group, life quality, and behavioral and environmental determinants using PRECEDE model [15]. This assessment was done using a review of the studies conducted, and a qualitative study was conducted. Finally, the results of the needs assessment were determined by identifying the health and life quality outcomes of the evaluation program.

In the review over the studies conducted to select the papers, Pubmed, scoups, Embase, and Google Scholar databases were searched for English papers and Iranmedex, SID, and Google Scholar databases 
for Persian ones. Given the differences in searching Iranian and foreign scientific databases, various Persian and English keywords were selected. The search was performed based on keywords among the papers of the past 5 years. After extracting the papers from the databases, the ones related to the topic were examined.

After coordination, an invitation letter was sent to all health educators and parents of teenage students (12-14 years) in Ardabil to participate in group discussion sessions to conduct the qualitative study. The samples were selected using purposive and voluntary sampling methods, and the main criterion for the inclusion was the individuals' willingness to participate in group interviews and their interest in working with project executives. After obtaining informed consent, the data were collected through 6 focus group discussions from 15 school health educators, 23 participating parents, and 20 teenage students (12-14 years). Sampling continued until data saturation (until the end of the fifth session) in all groups. The sessions were conducted by the researcher using a semi-structured index based on how the researcher interacted and discussed. All sessions and interviews were audio-recorded and transcribed by the researcher and analyzed following encoding in a basic thematic method. Finally, the results of the needs assessment were linked to the health planning and quality of life assessment and planning program[16].

\section{Step 2: Matrix}

The main tool in IMA is matrix of change objectives [17]. At this step, change objectives determine what to be done to reach performance goals to bring about changes in behavioral and environmental conditions and ultimately improve the life quality of the target group $[17,18]$. At this stage, the expected outcomes were performed in two distinct behavioral and environmental levels, focusing on these outcomes, and the next step was the expected outcomes divided by the performance goals [19] where the matrix of change objectives was obtained from the midpoint of the performance goals using determinants. In the present study, this matrix was designed to meet the three expected outcomes according to the results obtained from the first step.

\section{Stage 3: Theoretical methods and practical applications}

In the third step, while the planning team predicted the ideas of the plan, the theoretical methods affecting the determinants of change were selected, and practical solutions were selected, and the evaluation program was designed to implement the predicted theoretical methods.

\section{Step 4: Producing components and program materials}

At this step of designing the intervention program, while holding a group meeting with the participants and considering their priorities and suggestions, the implementation, scope, and implementation sequence themes of the program were identified along with the constraints. For instance, if one part of the program had been planned for the school program during the school year, the resources needed by the principal and teacher along with the financial constraints of the program and the stages of program implementation were determined. The planning team then decided on the intervention methods to 
achieve the goals of change, and finally pre-tested the messages and other parts of the program before final production.

\section{Step 5: Program implementation}

At this step, the tasks of the individuals and what they must do so that the outcome is fully met and implemented acceptably were determined. Then similar to Step 2, matrix planning was defined to guide the intervention program. In this matrix, the operational goals and determinants were determined for adoption, implementation and maintenance of the program. For instance, determinants responded to the question why do decision makers decide to use the program and why those in charge try to make sure the program continues over time? The answers to these questions determine the adoption, implementation, and maintenance of the program.

\section{Stage 6: Assessment planning}

In the final step, the assessment program was defined to determine the effectiveness of the program, and the extent to which the performance goals and objectives were changed. Assessment questions were identified from the defined outcomes and objectives, and a criterion was identified [20].

The results of the first step, needs assessment: The results of a review of studies (15 related papers) showed that Students' information on how to use a backpack and related injuries was low. Moreover, the majority of teenage students does not have a proper definition of backpack and how to use it, how to use a backpack bag, A variety of backpack bags. In this study, mothers and school health educators were the most reliable channel of transmission of information.

The results were categorized into 3 outcomes:1- Increasing student information about backpacks and musculoskeletal injuries 2- Increasing student information about all kinds of backpacks 3-Proper use of backpacks

\section{1- Increasing student information about backpacks}

The weight of backpack and musculoskeletal symptoms related to backpack carriage on student [20]. also back pain is a common affliction and a leading cause of disability in adults, but only recently has back pain been documented in teenage students [21]. ergonomics awareness and posture training is an important preventive approach to back pain, it is important for teenage students to learn about the structure of spine and back care [20]. One common suspect for back pain in children is the school backpack, which has also received a greater deal of attention in the past few years [22]. A study in Italy found that the average load of backpack was $22 \%$ of the student's weight and that $1 / 3$ of the student surveyed carried excess of $30 \%$ of their body weight at least one time per weak, their point prevalent for reporting back pain was nearly $16 \%$. With life time prevalence is estimated to be $48 \%$ [23].

\section{Increasing student information about All kinds of backpacks}


A backpack is a cloth sack put on somebody's back. It usually has two straps that go over the shoulders. People often use backpacks on camping trips, hikes, or any form of outdoor activity where people need to carry many things. Backpacks are also being used in the military by soldiers. It can be also used in school, or in this case, it also called a book bag or backpack [4]. It is important to increase students' knowledge of the types of backpacks and standard backpacks while most students choose their backpack according to its appearance why so studies show that most bags and school backpacks are not standard [24].

\section{Proper use of backpacks}

When the backpack load is greater than the carrying capacity of the muscle teenage students, there is overhead, reflecting the spine, causing pain, structural changes or dysfunction [25] Special attention has been paid when the weight is more than $15 \%$ of their body mass. According to the Italian Backpack Study, in Italy students carry backpacks with $22 \%$ of their body weight, and $34.8 \%$ of them carry backpacks with weight corresponding to $30 \%$ of their body weight, at least once a week, exceeding even the proposed limits for adult also They found that when carrying backpack with a load of $15 \%$ of body weight major changes occurs in angles of the head, neck affect the posture [26].

\section{Step 2:}

Results (objectives matrix): The planning team drafted the performance goals based on theories of planned self-efficacy at the beginning of this phase according to the 3 individual outcomes of the program. Then, they got help from a three-person group including a health education specialist, an adolescent psychologist, and a health educator to evaluate the validity, and based on their views, the drafted performance goals were revised (Tables 1 and 2).

Table 1 Individual-level matrix the first behavioral consequence: Increasing teenage student's information about backpacks

\begin{tabular}{|c|c|c|c|}
\hline Functional goals & Determinant 1 & Determinant 2 & Determinant 3 \\
\cline { 2 - 4 } & Awareness & Self-efficacy & $\begin{array}{c}\text { Behavior } \\
\text { barriers }\end{array}$ \\
\hline $\begin{array}{c}\text { Teenage students } \\
\text { know and express } \\
\text { tips about } \\
\text { backpacks and } \\
\text { proper use }\end{array}$ & $\begin{array}{c}\text { Change objectives: } \\
\text { teenage students state } \\
\text { the weight of standard } \\
\text { backpack }\end{array}$ & $\begin{array}{c}\text { Change objectives: } \\
\text { teenage students } \\
\text { regularly plan to use the } \\
\text { recommended about } \\
\text { proper use of backpack }\end{array}$ & $\begin{array}{c}\text { Change } \\
\text { objectives: } \\
\text { teenage } \\
\text { students' } \\
\text { express barriers } \\
\text { to proper use of } \\
\text { backpack }\end{array}$ \\
& $\begin{array}{c}\text { Teenage students } \\
\text { explain musculoskeletal } \\
\text { symptoms related to } \\
\text { heavy backpack carriage }\end{array}$ & & \\
\hline
\end{tabular}

\section{Second behavioral outcome: Increasing teenage student's information about All kinds of backpacks}




\begin{tabular}{|c|c|c|c|}
\hline \multirow[t]{2}{*}{ Functional goals } & $\begin{array}{c}\text { Determinant } \\
1\end{array}$ & Determinant 2 & Determinant 3 \\
\hline & Awareness & Self-efficacy & Behavior barriers \\
\hline $\begin{array}{c}\text { Increasing teenage } \\
\text { student's information } \\
\text { about all kinds of } \\
\text { backpacks }\end{array}$ & $\begin{array}{c}\text { Change } \\
\text { objectives: } \\
\text { teenage } \\
\text { students to } \\
\text { name } \\
\text { all kinds of } \\
\text { backpacks }\end{array}$ & $\begin{array}{c}\text { Change objectives: } \\
\text { teenage students are confident } \\
\text { in their ability for identification } \\
\text { and diagnosis economic back } \\
\text { pack }\end{array}$ & $\begin{array}{c}\text { Change objectives: } \\
\text { Teenage students } \\
\text { name barriers to } \\
\text { buy economic back } \\
\text { pack }\end{array}$ \\
\hline
\end{tabular}

Third behavioral outcome: Proper use of backpacks

\begin{tabular}{|c|c|c|c|}
\hline Functional & Determinant 1 & Determinant 2 & Determinant 3 \\
\cline { 2 - 4 } goals & Awareness & Self-efficacy & Behavior barriers \\
\hline Proper & Change objectives: & Change objectives: & Change objectives: \\
backpacks & $\begin{array}{c}\text { Teenage students } \\
\text { show proper use of } \\
\text { backpacks } \\
\text { Teenage students } \\
\end{array}$ & $\begin{array}{c}\text { Teenage students are sure } \\
\text { can use their backpacks } \\
\text { propress proper use of } \\
\text { backpacks }\end{array}$ & $\begin{array}{c}\text { Teenage students name } \\
\text { barriers use backpacks } \\
\text { properly }\end{array}$ \\
\\
\hline
\end{tabular}

Table 2 Interpersonal level matrix Behavioral outcome: Positive family support

\begin{tabular}{|c|c|c|}
\hline Functional goals & Determinant 1 & Determinant 2 \\
\cline { 2 - 3 } & Awareness & Self-efficacy \\
\hline $\begin{array}{c}\text { Family members talk to } \\
\text { teenage students } \\
\text { about their safe } \\
\text { backpack and all kinds } \\
\text { of it }\end{array}$ & $\begin{array}{c}\text { Change objectives: } \\
\text { Mothers are confident in their } \\
\text { ability to communicate with } \\
\text { Teenage students }\end{array}$ & $\begin{array}{c}\text { Change objectives: } \\
\text { not have recognize that if they do } \\
\text { with their teenage relationship } \\
\text { prefer non-standard bags }\end{array}$ \\
\hline $\begin{array}{c}\text { Mothers support } \\
\text { teenage students in } \\
\text { maintaining a healthy } \\
\text { diet }\end{array}$ & $\begin{array}{c}\text { Change objectives: } \\
\text { Mothers are confident in their } \\
\text { ability to support their } \\
\text { teenage students to buy a } \\
\text { beautiful ergonomic backpack }\end{array}$ & $\begin{array}{c}\text { Mothers are confident in their } \\
\text { ability to support their Teenage } \\
\text { students to buy a beautiful } \\
\text { ergonomic backpack }\end{array}$ \\
\hline \multicolumn{2}{|c}{} \\
\hline
\end{tabular}

\section{The results of step three, defining theoretical methods and practical applications}

In this step, the theoretical methods and practical applications for each determinant were defined with the participation of the planning team (Table 3).

Table 3 Theoretical methods, practical applications, communication tools channels 


\begin{tabular}{|c|c|c|c|c|}
\hline Determinant & $\begin{array}{c}\text { Theoretical } \\
\text { method }\end{array}$ & Definition & $\begin{array}{c}\text { Practical } \\
\text { application }\end{array}$ & Channel \\
\hline Awareness & $\begin{array}{c}\text { Group } \\
\text { discussion } \\
\text { Using } \\
\text { illustration }\end{array}$ & $\begin{array}{c}\text { Encouraging to explore the issue } \\
\text { in an open and informal debate } \\
\text { Using visual works that have a } \\
\text { similar symbol to the theme }\end{array}$ & $\begin{array}{l}\text { Educational } \\
\text { videos and } \\
\text { debates } \\
\text { Training } \\
\text { and debate } \\
\text { packages }\end{array}$ & $\begin{array}{l}\text { Interpersonal } \\
\text { Interpersonal }\end{array}$ \\
\hline \begin{tabular}{|l|} 
Self-efficacy \\
\end{tabular} & $\begin{array}{l}\text { Setting up } \\
\text { categorized } \\
\text { activities } \\
\text { Provision } \\
\text { of possible } \\
\text { rewards }\end{array}$ & $\begin{array}{l}\text { Determining simple activities and } \\
\text { increasing difficulty until the } \\
\text { target behavior is achieved. } \\
\text { Encouraging, or providing awards } \\
\text { clearly related to the achievement } \\
\text { of a particular behavior }\end{array}$ & $\begin{array}{l}\text { Educational } \\
\text { videos and } \\
\text { debates } \\
\text { Provision of } \\
\text { awards } \\
\text { Educational } \\
\text { videos and } \\
\text { debates }\end{array}$ & $\begin{array}{l}\text { Interpersonal } \\
\text { Interpersonal } \\
\text { and personal } \\
\text { Interpersonal } \\
\text { and collective } \\
\text { communication }\end{array}$ \\
\hline $\begin{array}{c}\text { Barriers to } \\
\text { behavior }\end{array}$ & $\begin{array}{l}\text { Changing } \\
\text { guidance }\end{array}$ & $\begin{array}{l}\text { Motivation change training, } \\
\text { whether consciously or } \\
\text { unconsciously, which describes } \\
\text { and identifies a behavior }\end{array}$ & $\begin{array}{l}\text { Educational } \\
\text { videos and } \\
\text { debates }\end{array}$ & $\begin{array}{l}\text { Interpersonal } \\
\text { and collective } \\
\text { communication }\end{array}$ \\
\hline
\end{tabular}

The results of step four: Intervention Planning: The intervention planning team identified the intervention implementation plan that includes the program sequence, program training channels, training materials, and how the program was implemented at each level [27]. The intervention program was designed over a period of 3 months for 3hours, one hour per week according to the specified sequence, and the best channel was selected based on theoretical methods and practical uses, interpersonal communication channel (For example: motion graphics) and mass media. In this step, a pre-test was designed and implemented to evaluate the overall program. The pre-test results showed the efficacy of most of the predicted theoretical methods and their implementation, and were applied where necessary. For instance, in a part of the intervention program to remove barriers health behaviors, the planning team had anticipated the individual commitment, and in practical application of this theoretical approach, a decision was made to prepare a recognizance [28]. The pre-test of the program showed that the individual commitment according to the mothers and teenage students participating in the study was not an appropriate approach, and finally the change in guidance suggested by parents and teenage students was validated as the theoretical method of removing the proposed behavioral barriers [29]. Thus, some changes were made in the program implementation at this point with some hints. Moreover, the presenters found that engaging in peer-to-peer discussion leads to better feedback and more effective interaction.

Results of Step Five (Adoption and implementation planning): At this stage, the theory of persuasive communication and programmed behavior plans were used to organize the adoption and implementation plans [29]. 
Results of the sixth stage (Evaluation planning): Since one of the significant goals of evaluation is using evaluation results [30], at this stage, the planning team identified the evaluation stakeholders - such as planners, study participants, program managers and executives - to evaluate the effect of the program, designed questions based on outcomes, performance goals, and individual and environmental determinants (Table 4). In this study, 30 students were selected to participate in the study performance. Those included attended training sessions for 4 weeks once a week [30] (not more than $5 \%$ of participants should have been absent in each training session).

Curriculum index: Individual and interpersonal performance change was determined. According to the studies conducted, the mothers and teenage student's behavior improvement index was considered to be $30 \%$ over one period of program implementation [31]. Then, a measurement tool was designed to evaluate the outcomes, behaviors, and determinants of personal and interpersonal levels. The evaluation program was implemented three months later, and to examine the made changes, the experimental study design with randomly dividing the participants into intervention and control groups was used [30].

Table 4 Evaluation of outcome, effect, and program process (sample questions) 


\begin{tabular}{|c|c|c|}
\hline & & Evaluating program outcomes \\
\hline Life qu & ality & $\begin{array}{l}\text { How much has the adherence to teenage student's health } \\
\text { behavior changed? (use proper backpack) }\end{array}$ \\
\hline Personal & level & $\begin{array}{l}\text { Do the teenage students do more healthy behaviors (use proper } \\
\text { backpack) after program implementation compared to before } \\
\text { program implementation? }\end{array}$ \\
\hline Interperso & al level & $\begin{array}{l}\text { Do mothers have more verbal and nonverbal communication with } \\
\text { their teenage students (about use proper backpack) after } \\
\text { program implementation? }\end{array}$ \\
\hline Assessment of & the effect of & program based on functional goals \\
\hline Personal & level & $\begin{array}{l}\text { Do the teenage students adhere to health behaviors (use proper } \\
\text { backpack) more after program implementation compared to } \\
\text { before? }\end{array}$ \\
\hline Interpersol & al level & $\begin{array}{l}\text { Do mothers support teenage students about ergonomic } \\
\text { backpack training and shopping after implementing health } \\
\text { behaviors more compared to before the implementation? }\end{array}$ \\
\hline nent of & effect of & change-based programs \\
\hline Personal & level & $\begin{array}{l}\text { Do the teenage students state the significance of observing } \\
\text { health behaviors (use proper backpack) after the program is } \\
\text { implemented? }\end{array}$ \\
\hline Interpersol & al level & $\begin{array}{l}\text { Do the mothers consider it important to have effective } \\
\text { conversations after the implementation? (use proper backpack) }\end{array}$ \\
\hline Determinant-b & sed progran & n effect assessment \\
\hline $\begin{array}{l}\text { Personal } \\
\text { level }\end{array}$ & Awareness & $\begin{array}{l}\text { Do teenage students report the disadvantages Non-ergonomic } \\
\text { backpack after the program is implemented? }\end{array}$ \\
\hline & $\begin{array}{c}\text { Self- } \\
\text { efficacy }\end{array}$ & $\begin{array}{l}\text { Do the teenage students feel more confident about adhering to } \\
\text { healthier behaviors (use proper backpack) after the program } \\
\text { compared to before? }\end{array}$ \\
\hline & $\begin{array}{c}\text { Behavioral } \\
\text { barriers }\end{array}$ & $\begin{array}{l}\text { Do the teenage students develop an appropriate program to } \\
\text { reduce the barriers to adhering to healthier behaviors (use } \\
\text { proper backpack) than before after implementing the program? }\end{array}$ \\
\hline $\begin{array}{c}\text { Interpersonal } \\
\text { level }\end{array}$ & $\begin{array}{c}\text { Self- } \\
\text { efficacy }\end{array}$ & $\begin{array}{l}\text { Do the mothers express greater confidence in supporting their } \\
\text { teenage students after the program has been implemented } \\
\text { compared to before? (use proper backpack) }\end{array}$ \\
\hline Assessment of & program d & elopment process \\
\hline Attainn & ient & $\begin{array}{l}\text { What proportion of the teenage student's community } \\
\text { participated in the program? }\end{array}$ \\
\hline Accur & & Is the educational curriculum done according to the protocol? \\
\hline Organizing th & e program & $\begin{array}{l}\text { Has the executive schedule been developed for the } \\
\text { musculoskeletal health program }\end{array}$ \\
\hline Program Index & & \\
\hline Improving mo & rs' behavi & r by $30 \%$ over one period of program implementation \\
\hline Improv & he beh & $\begin{array}{l}\text { ior of teenage students by } 30 \% \text { over one period } \\
\text { implementation }\end{array}$ \\
\hline
\end{tabular}


This program was done to design and develop How to use a backpack and reduce teenager musculoskeletal damage training program using IMA. The results indicated that IMA is a good step-bystep framework for developing a systematic and community-based program in teenage students. Moreover, IMA provides a practical and usable guide to adapt and promote health promotion programs for other planners to be used elsewhere [32]. It has to be noted that IMA is highly practical and user friendly [16]. Our results indicated that IMA can help develop a theory-based and evidence-based problem solving approach [33], produce outcomes, performance goals, change objectives, determinants, theoretical change methods, and practical applications and evaluation.

\section{Conclusion}

Intervention Mapping has been successfully used to plan, implement and evaluate educational interventions. This study has provided a good understanding of the role of intervention mapping in designing educational interventions for teenage student, and a good foundation upon which subsequent reviews can be guided.

\section{Abbreviations}

MH: Musculoskeletal Health; TSTP: Teenage Students Training Program; IMA: Intervention Mapping Approach

\section{Declarations}

\section{Acknowledgment}

This paper is the result of a research project approved by Vice chancellor for Research and Technology? The authors appreciate the support by respected authorities of Ardebil University of Medical Sciences and Ardebil General Education Department.

\section{Acknowledgments}

We are grateful to the Deputy for Research and Technology, Ardebil University of Medical Sciences, for cooperating in this research. The authors would like to thank all the participants who patiently participated.

\section{Authors'contributions}

NN, AZ and SST conceived and designed the study and finalized the methodology and tools used. NN and AZ collected the data and analyzed and drafted the manuscript. SST and JA helped with critical comments and drafting the final version of the manuscript. All the authors made significant contributions in the manuscript writing and finalizing of the manuscript. The final manuscript has been read and approved by all the authors. 


\section{Funding}

This study was drawn from a research project (No. 97064) sponsored by deputy of research and technology of AUMS. The cost of the payment is spent on the design and implementation of the study.

\section{Availability of data and materials}

Authors report that the data supporting their findings can be publicly shared.

\section{Ethics approval and consent to participate}

The study was approved by the Research Ethics Committee of Ardabil University of Medical Sciences (Code: IR.KUMS.REC.1397.064). Written informed consent was obtained from group members. All the procedures performed in the study involving human participants were based on the ethical standards of the Institutional Research Committee and the Helsinki Declaration and its later amendments or comparable ethical standards.

\section{Consent for publication}

All participants consented verbally to publication of the interview data.

\section{Competing interests}

The authors declare that they have no competing interests

\section{Author details}

${ }^{1}$ Health Promotion and Education, Department of Health Promotion and Education, Ardabil University of Medical Sciences, Ardabil, Iran. ${ }^{2} \mathrm{PhD}$ in Health Promotion and Education, Professor of Health Education \& Health Promotion, Tarbiat Modares University, Tehran, Iran. ${ }^{3}$ Health Education and Health Promotion, Health Institute, Kermanshah University of Medical Sciences, Kermanshah, Iran. ${ }^{4}$ Antai College of Economics and Management/School of Media and Communication, Shanghai Jiao Tong University, Shanghai, China.

\section{References}

1. Sistani N, Khoi M, Taghdisi M. Promoting knowledge, attitude and practices (KAP) of the mothers in their Girls' pubertal health based on peer education approach. J Babol Univ Med Sci. 2010;11(6):33-9.

2. Mansoorian M, Ghasemi MS, Forough B, Dehghan N. Evaluating the impact of a new ergonomic backpack designed on foot plantar pressure and perceived comfort by its users. Iran Occup Health. 2018;15(5):59-68.

3. Zakeri Y, Baraz S, Gheibizadeh M, Saidkhani V. Relationship between backpack weight and prevalence of lordosis, kyphosis, scoliosis and dropped shoulders in elementary students. Int $J$ 
Pediatr. 2016;4(6):1859-66.

4. Kistner F, Fiebert I, Roach K, Moore J. Postural compensations and subjective complaints due to backpack loads and wear time in schoolchildren. Pediatr Physical Therapy. 2013;25(1):15-24.

5. Grarmaroudi GR, Makarem J, Alavi SS, Abbasi Z. Health related risk behaviors among high school students in Tehran, Iran. Payesh (Health Monitor). 2010;9(1):13-9.

6. Peters G-J. A practical guide to effective behavior change: how to identify what to change in the first place. European Health Psychologist. 2018;16(4):142-55.

7. Farahani FKA, Cleland J, Mehryar AH. Associations between family factors and premarital heterosexual relationships among female college students in Tehran. Int Perspect Sexual Reproduct Health. 2011;37(1):30-9.

8. Schuiling. Women's Gynecologic Health. Jones \& Bartlett Learning. p. 22. ISBN 978-1-284-12501.6The changes that occur during puberty usually happen in an ordered sequence, beginning with thelarche (breast development) at around age 10 or 11, followed by adrenarche (growth of pubic hair due to androgen stimulation), peak height velocity, and finally menarche (the onset of menses), which usually occurs around age 12 or 13. 2016.

9. Shamsoddini A, Hollisaz M, Hafezi R. Backpack weight and musculoskeletal symptoms in secondary school students, Tehran, Iran. Iran J Public Health.120-8:(4)39;2010 .

10. Lloyd-Smith W. Evidence-based practice and occupational therapy. British J Occupat Therapy. 1997;60(11):474-8.

11. Crombie IK, Harvey BJ. The pocket guide to critical appraisal: a handbook for health care professionals .Canadian Med Associat J. 1997;157(4):448-506.

12. Navuluri N, Navuluri RB. Study on the relationship between backpack use and back and neck pain among adolescents. Nurs Health Sci. 2006;8(4):208-15.

13. Haselgrove C, Straker L, Smith A, O'Sullivan P, Perry M, Sloan N. Perceived school bag load, duration of carriage, and method of transport to school are associated with spinal pain in adolescents: an observational study. Australian J Physiotherapy. 2008;54(3):193-200.

14. Chow D, Ou Z, Wang X, Lai A. Short-term effects of backpack load placement on spine deformation and repositioning error in schoolchildren. Ergonomics. 2010;53(1):56-64.

15. Standards JCoNHE. National health education standards: Achieving excellence: American Cancer Society; 2007. Retrieved May 1, 2009, from https://www.cdc.gov/HealthyYouth/SHER/standards/index.htm p.

16. Foxcroft DR, Ireland D, Lister-Sharp DJ, Lowe G, Breen R. Longer-term primary prevention for alcohol misuse in young people: a systematic review. Addiction. 2003;98(4):397-411.

17. Kiyalashki A. Postmenopausal menstrual disorders among female students of Babol high schools in year 2000. Master thesis of Midwifery. Iran Univ Med Sci, Tehran, Iran. 2000.

18. Kok G, Lo SH, Peters G-JY, Ruiter RA. Changing energy-related behavior: An Intervention Mapping approach. Energy Policy. 2011;39(9):5280-6. 
19. Bartholomew LK, Parcel GS, Kok G. Intervention mapping: a process for developing theory and evidence-based health education programs. Health Educ Behav. 1998;25(5):545-63.

20. Frumkin H, Geller RJ, Rubin IL, Nodvin J. Safe and healthy school environments: Oxford University Press; 2006.

21. Murphy S, Buckle P, Stubbs D. Classroom posture and self-reported back and neck pain in schoolchildren. Applied Ergonom. 2004;35(2):113-20.

22. Wyatt LH. Handbook of clinical chiropractic care: Jones \& Bartlett Learning; 2005.

23. Negrini S, Carabalona R. Backpacks on! Schoolchildren's perceptions of load, associations with back pain and factors determining the load. Spine. 2002;27(2):187-95.

24. Peters G-JY, De Bruin M, Crutzen R. Everything should be as simple as possible, but no simpler: towards a protocol for accumulating evidence regarding the active content of health behaviour change interventions. Health Psychology Rev. 2015;9(1):1-14.

25. Ramprasad M, Alias J, Raghuveer A. Effect of backpack weight on postural angles in preadolescent children. Indian Pediatr. 2010;47(7):575-80.

26. Precenzano F, Ruberto M, Parisi L, Salerno M, Maltese A, D'alessandro I, et al. ADHD-like symptoms in children affected by obstructive sleep apnea syndrome: a case-control study. Acta Med Mediterranea. 2016;32:1755-9.

27. Grunbaum JA, Kann L, Kinchen SA, Williams B, Ross JG, Lowry R, et al .Youth risk behavior surveillance-United States, 2001. J School Health. 2002;72(8):313-28.

28. Herbold NH, Frates SE. Update of nutrition guidelines for the teen: trends and concerns. Current Opinion Pediatr. 2000;12(4):303-9.

29. Nicklas TA, Bao W, Webber LS, Berenson GS. Breakfast consumption affects adequacy of total daily intake in children. J Am Dietetic Associat. 1993;93(8):886-91.

30. Azmoude E, Jafarnejade F, Mazlom SR. The predictors for maternal self-efficacy in early parenthood. J Mid Reproduct Health. 2015;3(2):368-76.

31. Ali TS, Rizvi SN. Menstrual knowledge and practices of female adolescents in urban Karachi, Pakistan. J Adol. 2010;33(4):531-41.

32. Sedghi Sabet M ,Hasavari F, Saied Fazel Poor F. A Survey Of Knowledge, Attitude, And Health Behaviour Of Girl Studeuts About Puberty. J Guilan Univ Med Sci. 2003;12(47):31-8.

33. Peters G-J. A practical guide to effective behavior change: how to identify what to change in the first place. European Health Psychologist. 2018;16(4):142-55. 